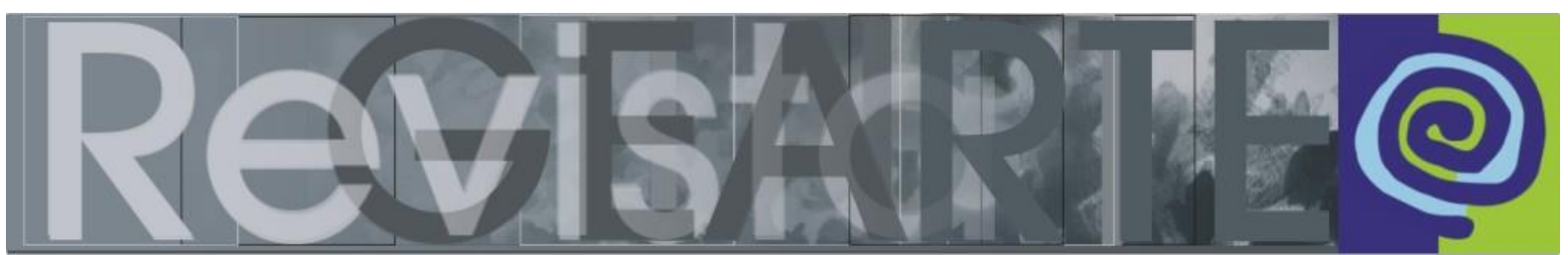

ISSN 2357-9854 | e-ISSN 2596-3198 (online)

\title{
Desaprendizagens permanentes: experiências com a arte na Pedagogia
}

\author{
Olga Egas
}

(Universidade Federal de Juiz de Fora — UFJF, Juiz de Fora/MG, Brasil)

RESUMO - Desaprendizagens permanentes: experiências com a arte na Pedagogia - Este texto apresenta reflexões sobre educação, docência e arte, bem como expectativas sobre o início e término de um percurso possível para a disciplina Fundamentos Teórico Metodológicos em Arte I no curso de Pedagogia, considerando os desafios e as responsabilidades compartilhadas entre professora e estudantes, futuros professores.

\section{PALAVRAS-CHAVE}

Educação. Formação docente. Arte.

ABSTRACT - Permanent unlearning: experiences with Art in Pedagogy - This text presents reflections on education, teaching and art, as well as expectations about the beginning and end of a possible path for the discipline Theoretical Methodological Foundations in Art I in the Pedagogy course, considering the challenges and shared responsibilities between teacher and students, future teachers.

KEYWORDS

Education. Teacher training. Art.

RESUMEN - Desaprendizaje permanente: experiencias con el arte en la Pedagogía - Este texto presenta reflexiones sobre la educación, la docencia y el arte, así como las expectativas sobre el inicio y el final de un posible camino para la disciplina Fundamentos Metodológicos Teóricos en Arte I en el curso de Pedagogía, considerando los desafíos y responsabilidades compartidas entre docente y alumnos, futuro. profesores.

PALABRAS CLAVE

Educación. Formación docente. Arte. 


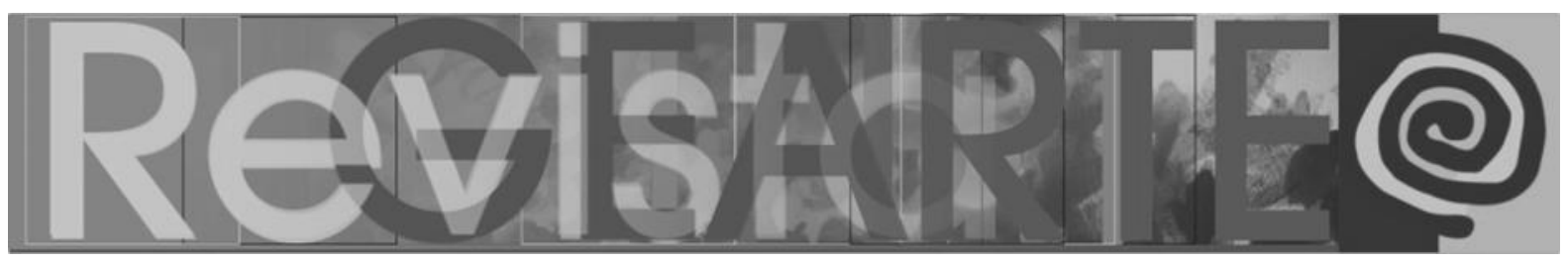

Este é um relato que apresenta reflexões sobre o primeiro e o último dia de aula e sobre o "estar entre" nos encontros semanais da disciplina Fundamentos Teórico Metodológicos em Arte I, no quinto período noturno do curso de Pedagogia, da Faculdade de Educação na Universidade Federal de Juiz de Fora, Minas Gerais, ocorrida entre agosto e novembro de 2019.

\section{Primeira aula}

Percorro os corredores da Faculdade de Educação, subo as escadas e chego na sala 19, quinze minutos antes do horário de início da aula. Acendo as luzes, posiciono meu material sobre a mesa, abro as janelas e deixo a porta aberta. Escrevo, com giz na lousa, o nome da disciplina, o meu nome e o e-mail para nossas trocas de mensagens. Verifico que as carteiras estão arrumadas em forma de "U", a TV e computador estão desligados e, talvez, prontos para uso. Olho através da janela e vejo o movimento de ir e vir das pessoas lá fora. Percebo que estou ansiosa e outra vez com aquele friozinho na barriga antes da primeira aula, então, meus pensamentos disparam... Esta não é a minha primeira turma e não será a última, mas, os minutos que antecedem o primeiro contato com a turma desencadeiam expectativas e um turbilhão de inquietações: será que fiz as escolhas certas para este grupo? quais demandas os estudantes trazem? construiremos laços? será que convivem com a arte? validam a arte na escola? como veem a Educação? por que querem ser professores? como contribuir com a formação desses futuros professores? Diante desse estado de suspensão e das incertezas fluídas, respiro fundo, busco alento na minha própria experiência docente e sinto-me imensamente feliz por ser professora há tanto tempo... Foi, para minha vida, a escolha certa!

Como professora universitária, formadora de professores, acredito que a licenciatura é um espaço para cuidar de si e para cultivar-se, o que amplia as possibilidades do existir mais sensível e estético. Empresto essas palavras de Virgínia Kastrup que vê o professor como "[...] potência de invenção, de si e do mundo" (KASTRUP, 1999). Por isso, o início de uma nova turma é sempre um 


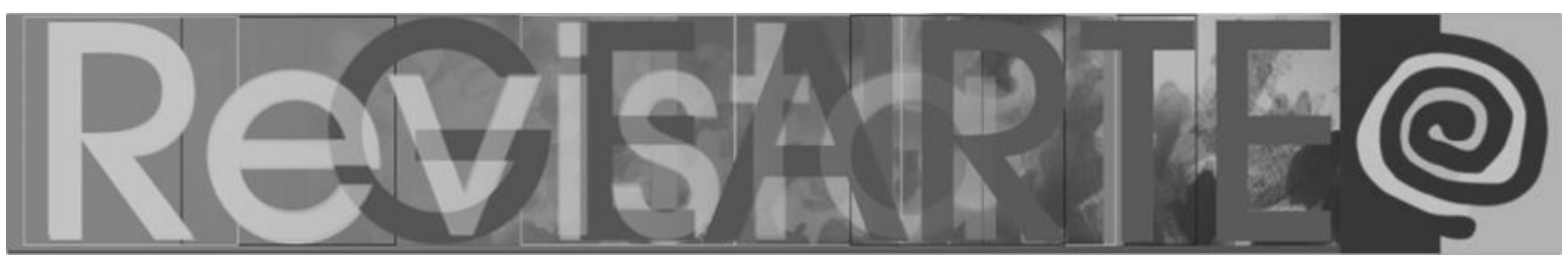

acontecimento simultaneamente, delicado e complexo. É meu propósito manter os futuros professores em "[...] estado de invenção" (KASTRUP, 1999), quiçá autores reflexivos e dinâmicos de sua própria prática, competentes para escapar dos conteúdos rotinizados tão comuns nas escolas e reinventar outras práticas para lidar com os objetos e os acontecimentos da escola. Mas, a carga horária da disciplina é tão exígua para ressignificar a arte, seu ensino e, ainda construir a docência com artisticidade...

Sendo essa a única disciplina obrigatória sobre a arte e seu ensino ao longo da formação dos pedagogos - embora haja, semestralmente, a oferta de disciplinas eletivas ${ }^{1}$ que, por várias circunstâncias, podem não acessar a todos os alunos - é primordial zelar para que cada encontro seja único. Contemporaneamente, a função da escola e, por extensão, da universidade, é favorecer a construção de subjetividades, de tal modo que os estudantes tenham estratégias e recursos para interpretar o mundo no qual vivem e, ainda, possam escrever sua própria história. Novamente, respiro pausadamente.

Bem, a turma vai chegando aos poucos. Observo como os estudantes chegam e escolhem seus lugares na sala de aula. Aparentemente, a maioria deles se conhece, pois se confraternizam alegremente. Alguns buscam os lugares ao lado dos amigos de sempre, outros se sentam em carteiras isolados, o que me faz pensar que são alunos desperiodicizados ${ }^{2}$ ou, talvez, estudantes do período da manhã. A turma tem 34 alunos, sendo 4 homens, reafirmando a majoritária presença feminina na Educação Infantil e Anos Inicias do Fundamental.

Para início da primeira conversa coletiva, proponho a apresentação pessoal e um breve comentário sobre as lembranças da arte na escola ou fora dela. A grande maioria dos presentes afirma não ter tido aula de arte ou não se lembram da disciplina em sua vida escolar. No entanto, fazem referência às vivências artísticas no contra turno escolar, durante a Educação Básica em teatro, desenho, música, capoeira e dança urbana nas oficinas do Programa Gente em Primeiro Lugar, promovido pela Funalfa ${ }^{3}$ - contudo, atualmente, não desenvolvem nenhuma 


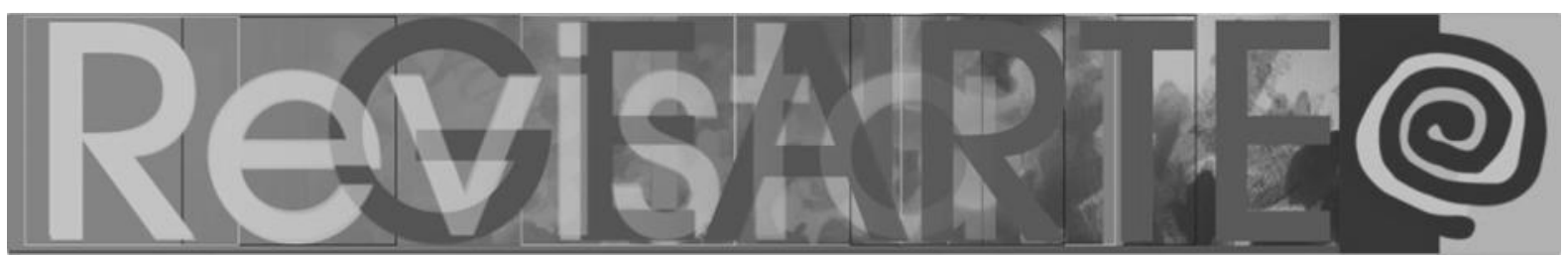

delas. Três alunas fazem apresentações de dança nos cultos de suas igrejas neopentecostais e outros quatros alunos, cantam e/ou tocam diferentes instrumentos nos cultos religiosos, com formação específica adquirida no conservatório da cidade. Entre lembranças em comum e muitas risadas, essa conversação inicial contribuiu para aquecer o reencontro do grupo e, no meu caso, desvelar um panorama sobre o quanto usufruem da arte, seja nos aparatos culturais da cidade, seja em seu tempo livre.

Há cabelos loiros, castanhos, negros, azuis, lisos, enrolados, cacheados, todos desvelando as misturas étnicas que nos constituem como brasileiros. Há alunas vestindo o uniforme das escolas onde estagiam ou das empresas onde, provisoriamente, ganham o pão. Algumas já lecionam e, entre elas, uma possui escola de Educação Infantil. Enquanto alguns trazem o próprio lanche/marmita de casa, outros podem desfrutar dos salgadinhos disponíveis para compra na cantina.

A turma é diversa também em outros aspectos. A faixa etária varia entre 22 e 36 anos. Há jovens mães e mães de adolescentes, alunos que ainda moram com a família e outros que residem só ou em repúblicas. Há alunos cursando a segunda graduação - por opção, por não se adaptarem à escolha profissional inicial ou por não concluírem o curso - e, outros, que, sem a pontuação necessária para efetivar a primeira opção no processo seletivo da universidade, escolheram a pedagogia como segunda alternativa. Mesmo sem a desejável intencionalidade na escolha profissional, afirmaram estar satisfeitos com o curso, (re)descobrindo novas habilidades e interesses pessoais, além de estarem ansiosos por atuarem na área. Curiosamente, o maior grupo de alunos sempre quis ser professor e não justificaram tal escolha de forma ingênua, como dizer, apenas, que gostam das crianças. Foram influenciados e amparados por bons exemplos profissionais, em casa ou na escola - de certa forma, ecoando esperança e utopias futuras. Na grande maioria, são a primeira geração da família a ascender à universidade pública e almejar um diploma de graduação para sua qualificação profissional. Certamente são o orgulho da família e o exemplo a ser seguido em suas comunidades. 


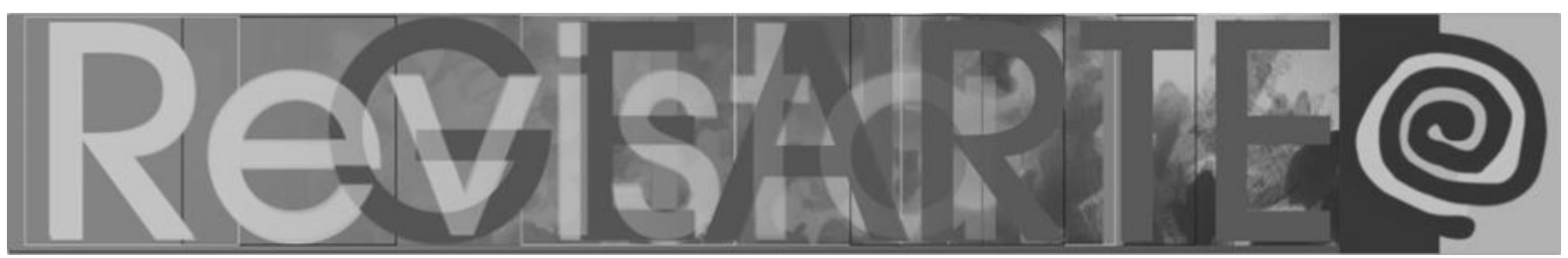

Em tempos de notória desqualificação do professor e da educação pública, a formação inicial docente, mais do que nunca, é um terreno fértil e movediço. Isto porque diferentes experiências pessoais e educativas ao longo da vida, impactam o processo formativo dos pedagogos e das pedagogas com suas expectativas pessoais, subjetividades, afetos, devaneios, visões de mundo, impaciência, maturação, reflexão, descompassos e sofrimento. No contexto da turma, aposto que há, também, desejos para o futuro, assim como a possibilidade concreta de inventar caminhos e de fazer escolhas coerentes e sensíveis. Enquanto ouço os relatos individuais, reconheço minha responsabilidade nesse processo formativo e a importância fundamental das Universidades Públicas ao garantirem o acesso e a manutenção dos alunos na Instituição.

Durante a conversação coletiva, surgem relatos sobre as atividades artísticas observadas durante os estágios na Educação Infantil. As alunas apontam certo desconforto ao assistir as regentes de sala direcionado e interferindo com a chamada "mão de gato" nas produções das crianças, que releva o espaço da imaginação e a experimentação artística ao tempo que "sobra", quase sempre na sexta feira, próximo ao encerramento do expediente letivo.

As narrativas confirmam que a linguagem visual se restringe à colorização de desenhos prontos, desde que dentro dos contornos, atrelados à ideia genérica de desenvolvimento da coordenação motora ou, ainda, desenho livre sobre folhas brancas de sulfite, sem nenhum estímulo ou orientação por parte da regente. Por vezes, as regentes avaliam os desenhos como bons ou ruins diante das crianças e pedem para refazê-los. Nesse jogo de tudo ou nada, em que as crianças só podem preencher o desenho dado nas áreas restritas ou fazer um desenho tecnicamente livre, mas colorido com as cores certas, como a criança pode elaborar seus pensamentos e exercitar a sua imaginação?

A pintura é pouco utilizada pois, segundo as regentes, "faz muita sujeira e as mães reclamam do uniforme manchado" - dizem elas. As músicas ouvidas durante os estágios relacionam-se ao adestramento do comportamento infantil, 


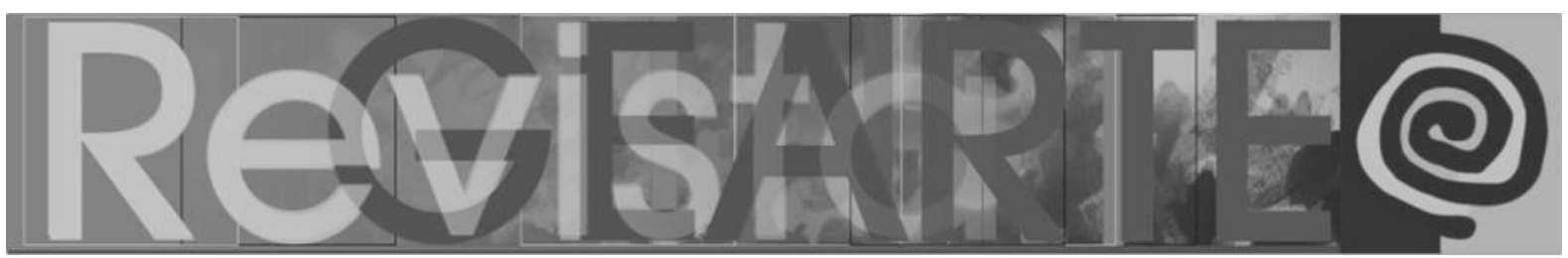

seja para silenciar a turma, iniciar o lanche e a higiene pessoal, marcar o início e o fim das atividades ou ainda, reproduzir os hits da mídia e suas coreografias. Movimentos livres e a exploração corporal e espacial não foram incentivados, ao contrário, são repreendidos em nome da ordem e disciplina "necessárias" para a concentração dos pequenos, segundo as regentes de classe. Diante dos fatos, alunas e alunos demonstram certo incômodo e percebem a inadequação dessas ações, porém, neste momento, ainda não alcançam as implicações pedagógicas dessas escolhas e a precariedade do contexto escolar observado.

Escuto os relatos dessas práticas docentes, velhas conhecidas, que se manifestam em variáveis docentes de despreparo, descaso e insensatez. Creio que a insuficiente valorização das linguagens artísticas em salas da Educação Infantil e dos Anos Iniciais do Fundamental está atrelada, entre outros motivos, aos projetos políticos pedagógicos dos cursos de Pedagogia, incluindo a instituição onde atuo, que não privilegiam as disciplinas relacionadas a arte e seu ensino nem tampouco, discussões sobre as culturas que nos constituem. Confirmado na apresentação pessoal da turma, enquanto estudantes da Educação Básica também não experimentaram a arte na escola. Assim, sem familiaridade e sem vivência com os processos artísticos, o futuro professor não valida a arte como linguagem e como conhecimento. Sem atribuir sentido à arte $e$ as suas manifestações, como poderão torná-las presentes em suas futuras regências? "Não se pode encorajar o outro a viver uma aventura que você mesmo não viveu" afirma a professora Ana Angélica, em seu livro O Espaço do desenho: a educação do educador (2010, p.121).

Entre as outras razões que impedem a presença efetiva da arte nas escolas de Educação Infantil e anos iniciais do Fundamental, está a produtividade imposta aos pequenos desde a mais tenra idade, afinal, não há tempo a perder com brincadeiras e com a curiosidade pueril. Nesse sentido, é preciso abarrotar o tempo escolar com muitas atividades impressas, por vezes, definidas nas apostilas dos sistemas de ensino, ou ainda, prepará-los para as inúmeras avaliações institucionais que virão. Também, é bastante comum a argumentação de que os 


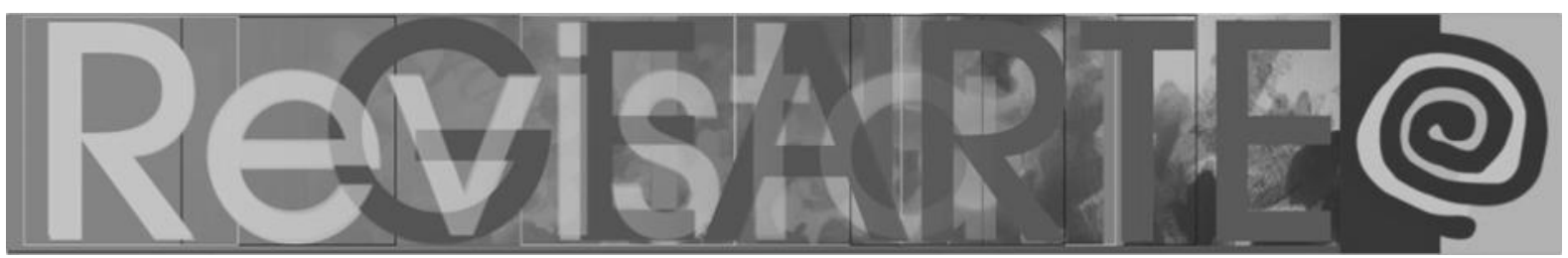

materiais artísticos necessários para as aulas de arte são caros para compra, como se a invenção e a imaginação não fossem materiais inesgotáveis e inerentes a essa faixa etária. No entanto, manifestações pseudo-artísticas, produzidas em sua grande maioria pelas próprias regentes e por suas auxiliares, surgem para decorar os painéis da sala de aula e os corredores, celebrar as datas comemorativas e as festas de encerramento letivo, com a presença dos pais e dos familiares; ainda, a elaboração dos presentes artesanais para o dia das mães e da família - um jogo de aparências, que na verdade, falseiam a realidade, subestimam os modos de fazer infantil, mas cumprem as expectativas entre família/direção e asseguram as relações comerciais entre pais e a escola particular.

Sob meu ponto de vista, para além da indignação diante desses fatos, considero que são temas que precisam ser abordados e esclarecidos durante a formação inicial dos futuros pedagogos, para que possam contribuir com as mudanças necessárias no chão da escola. Esses cenários polêmicos continuam impulsionando minhas reflexões e ações, na tentativa de tornar a compreensão da própria formação uma experiência relevante entre os estudantes.

Assumo a conversa coletiva e também me apresento: "sou uma professora que gosta de ser professora e talvez isso se reflita nas opções que realizarei ao longo da disciplina" - digo. Sou interrompida por uma aluna que diz nunca ter ouvido antes tal afirmação na Faculdade de Educação - para minha surpresa. Como os demais professores universitários, formadores de professores, veem suas opções profissionais? Será que ainda alimentam em si os mesmos motivos das escolhas iniciais? A sobrecarga das tarefas acadêmicas (ensino, pesquisa, extensão) e por vezes, também administrativa, contribui para diminuir a alegria e a positividade? Gostar do que se faz: como isso afeta o professor? Como afeta os alunos?

Como não se trata de dar respostas, solicito à turma outras opiniões sobre gostar de ser professor/a e a conversa segue, indagando motivos da escolha e permanência na profissão; enfrentamento das dificuldades; baixa estima e 


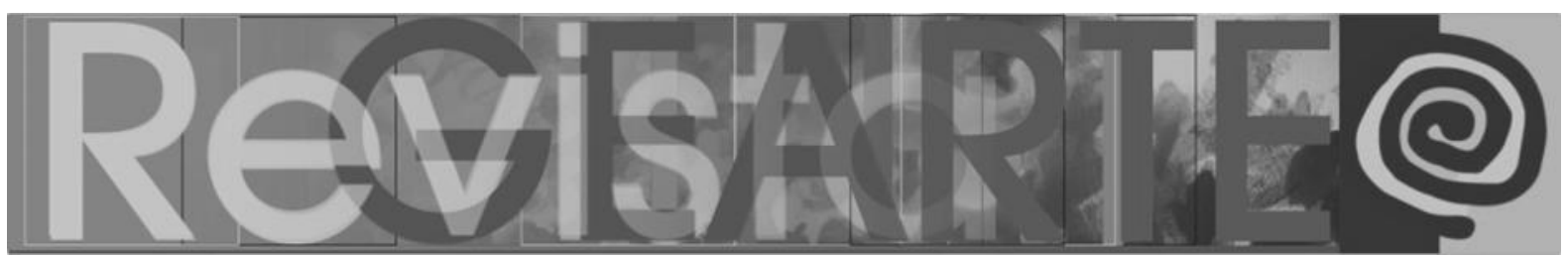

inseguranças; imagem e credibilidade dos professores; importância e desqualificação atual da educação. Como vemos, a formação inicial dos pedagogos e pedagogas é extremamente complexa e abrangente - ou deveria ser!

Comento rapidamente sobre minha formação, experiência profissional e como cheguei na UFJF, vinda da capital paulistana. Realizei o processo seletivo e fui aprovada como professora na área de ensino de arte na Faculdade de Educação. Desde então, entre desafios e descobertas pessoais e profissionais, muitas dúvidas e algumas certezas, vou reinventando a profissão que escolhi há tempos atrás. Finalizo declarando que na educação não existe apenas um caminho, mas, sim, vários! As escolhas dependem das nossas intenções profissionais e da disponibilidade pessoal para estudar muito, aprender sempre, gostar de estar entre pessoas e, claro, gostar do que faz! Meu intuito não é romantizar a profissão, nem tampouco só valorizar o magistério na academia, mas, dar a ver que a educação é desafiadoramente instituída por e para pessoas.

Apresento a disciplina na qual abordaremos o ensino e a aprendizagem da arte no cotidiano escolar, considerando três aspectos: 1. A educação e a escola que precisamos; 2. A escola e o ensino de arte: os processos de criação e as linguagens artísticas: artes visuais, música e movimento (dança/teatro); 3 . Arte e as culturas: o professor pesquisador e o resgate do seu olhar sensível, o ambiente de sala de aula, o aprendiz da arte, a arte e as culturas na cidade. Reforço, ainda, que além das aulas expositivas e dialogadas sobre as linguagens artísticas, faremos leituras e discussões sobre textos, imagens e audiovisuais, trabalhos práticos e teóricos, individuais e coletivos e saídas culturais. Considerando a natureza prático-reflexiva da disciplina, deixo claro que não há possibilidade de recuperação ou reposição de aulas. Com isso, reafirmo que a presença e participação de todos é fundamental para a dinâmica das aulas e a aquisição dos conhecimentos relativos ao campo da Arte-Educação. Agora, vamos lá fazer o que será... 


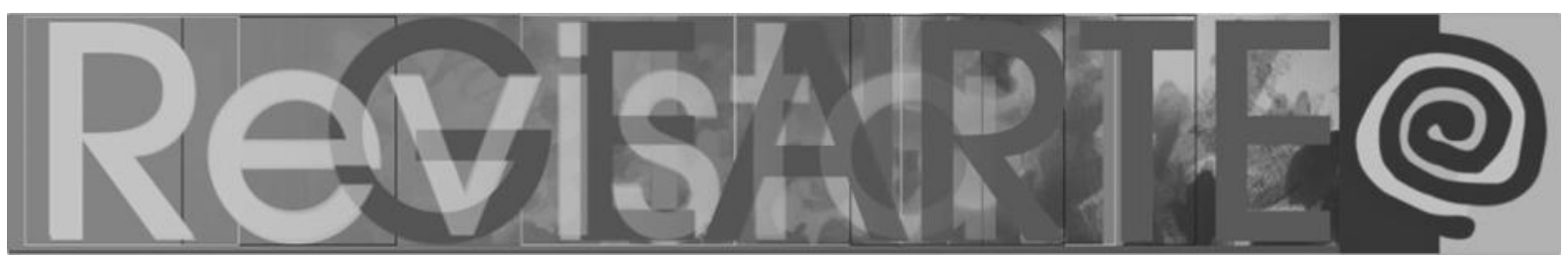

Entrego, a todos os alunos e alunas, uma folha de papel sulfite branca, tamanho A5, com as seguintes orientações: de um lado, escreva um pequeno texto sobre para que arte na escola e no verso, desenhe uma figura humana, à lápis, caneta ou outro material disponível - sem nenhuma outra instrução de minha parte. Essa folha identificada foi recolhida por mim e será devolvida ao final da disciplina - como materialização dos avanços ocorridos ao longo das aulas a partir dos registros aqui realizados.

Em seguida, assistimos ao curta metragem O fim do Recreio, dirigido por Vinícius Mazzon e Nélio Spréa (17:32', 2012), produzido por Parabolé Educação e Cultura, de Curitiba, PR, com o seguinte release:

No Congresso Nacional, um projeto de lei pretende acabar com o recreio escolar. Ao mesmo tempo, em uma escola municipal de Curitiba, um grupo de crianças pode mudar toda essa história. Recheado de vibrantes brincadeiras infantis, O Fim do Recreio é um curta-metragem para todos os públicos, que bota a boca no trombone e avisa: cobra parada não come sapo! (O FIM DO RECREIO, 2012, n.p)

Os comentários da turma, pós exibição, conjecturaram a importância do brincar e dos tempos de brincar livremente na escola, as brincadeiras tradicionais coletivas e a dar voz aos alunos, entre outras questões. Embora produzido em 2012, o filme apresenta reflexões pertinentes para os dias de hoje.

Também assistimos à animação Mudando Paradigmas Educacionais ${ }^{4}$ (MUDANDO, 2003), adaptação da palestra do professor Sir Ken Robinson, especialista em educação e criatividade. Nessa animação, o professor aponta os problemas do atual sistema educacional, desenhado ainda no século 19, que não contempla as demandas do século 21 , entre outras, o trabalho coletivo e a criatividade. A conversa que se seguiu na aula trouxe à tona novas inquietações sobre a educação, a escola, os professores e seus alunos. A origem da educação pública, como foi construída e o que temos hoje. Afinal, por que separamos os alunos por faixa etária e não por seus interesses e habilidades? Por que a criatividade vai perdendo força na resolução dos problemas à medida em que a escolarização aumenta? Enfim, seguimos com maiores perguntas... 


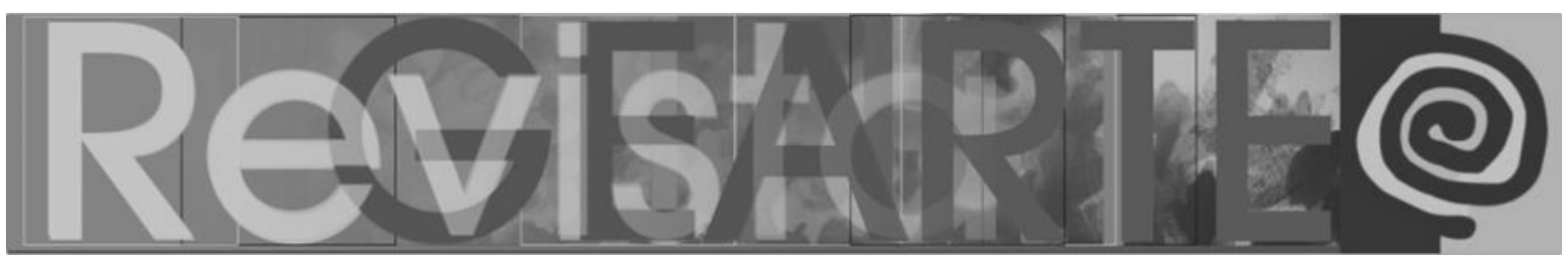

A partir de agora, as aulas serão iniciadas com uma agenda cultural, sustentada por sugestões de leituras, filmes, séries, shows e eventos na cidade, indicados pela turma de tal forma que poderemos experienciar as culturas e nos cultivar em nossas semelhanças e diferenças. Para encerrar o primeiro encontro, proponho a elaboração de um diário de bordo, para além das anotações acadêmicas e/ou da rotina estudantil de sempre. Vale registrar pensamentos sobre a docência, advindos de todas as disciplinas formativas realizadas na Faculdade de Educação (Faced), bem como reflexões pessoais sobre os estágios, a educação e o ensino de arte, as surpresas e descobertas, as metodologias inspiradoras, novas inquietações e desejos futuros e tudo o mais que contribua para transver o mundo. Vale escrever poeticamente, desenhar, colar, pintar, fotografar e tudo que inventarem para retomar/rememorar sempre que quiser e precisar, pois, muitas vezes, ao longo da profissão, precisamos recuperar os motivos que nos levaram a escolha profissional. O diário individual será apresentado para a turma na última aula, apenas para apreciação dos diferentes registros.

Anunciei o envio do e-mail coletivo, da síntese de cada aula, para que todos tenham o registro dos conteúdos trabalhados, incluindo dicas e links sugeridos ao longo da aula, proporcionando, aos ausentes, as condições de acompanhar o que perderam. Como não há mais questões, encerramos a primeira aula. Junto o meu material, fecho as janelas e apago as luzes. Tranco a chave da porta e, descendo as escadas, sinto o cansaço, então, respiro fundo. Por hoje, valeu! 


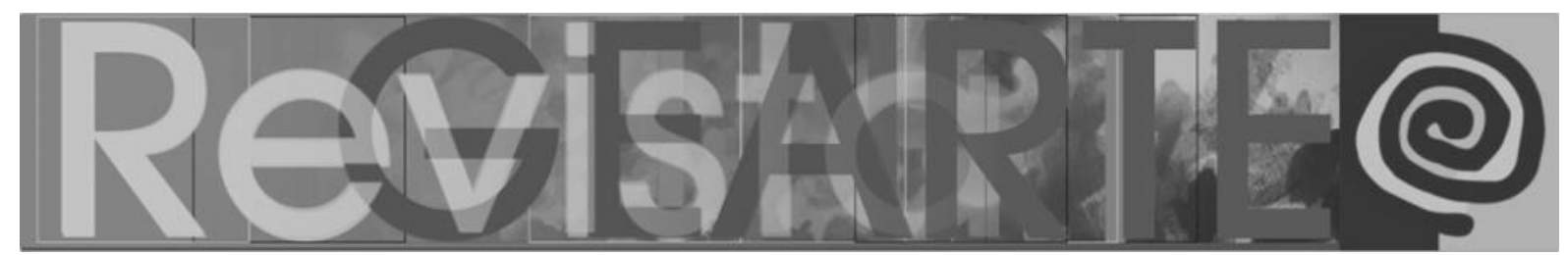

Figura 1 - Aprendizagens I

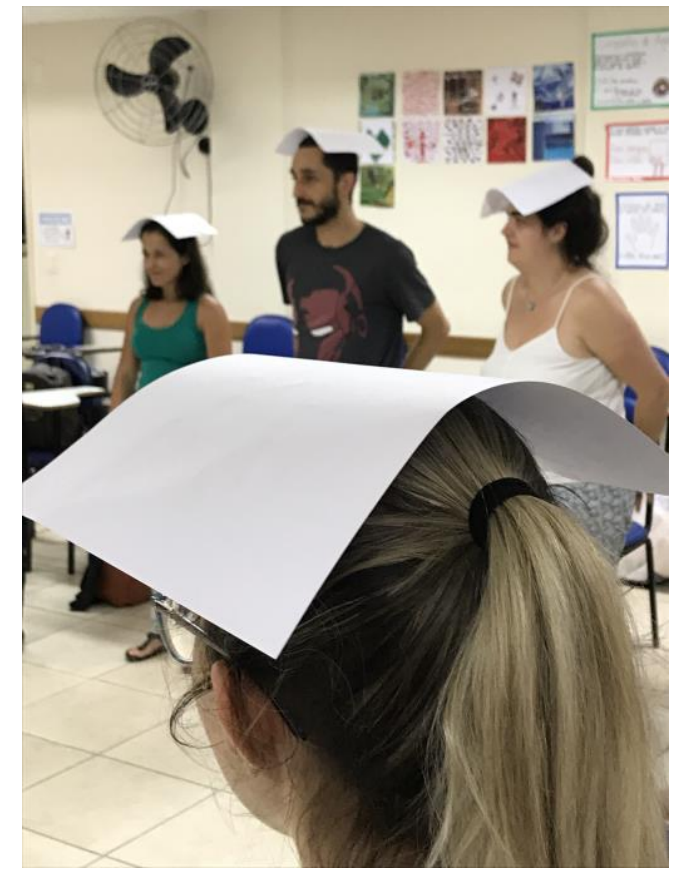

Fonte: Acervo da autora (2019)

\section{Entre estranhamentos e surpresas}

"Não gosto de palavra acostumada"

(BARROS, 2000, p. 71)

Kastrup (2005, p. 1280) afirma que "[...] invenção não é uma capacidade de solução de problemas mas, sobretudo, de invenção de problemas". Manter-se em estado de invenção é manter-se atento e disponível ao vaivém das soluções/invenções de problemas, entre fluxos de inacabamentos, dúvidas e erros que se tornarão aprendizagens futuras.

Ao compartilhar experiências, vivenciamos desaprendizagens permanentes; ao inventar problemas, possibilitamos a construção de subjetividades; ao produzir múltiplas ferramentas de leitura e interpretação do mundo, desenhamos a nossa própria história - condição indispensável ao ofício de qualquer professor. Nesse sentido, planejamos proposições entre arte, educação e cultura, para instigar a sensibilidade estética de alunos e alunas, de futuros professores, entre as quais, destacamos as seguintes: A poética pessoal para transver o mundo; O desenho para 


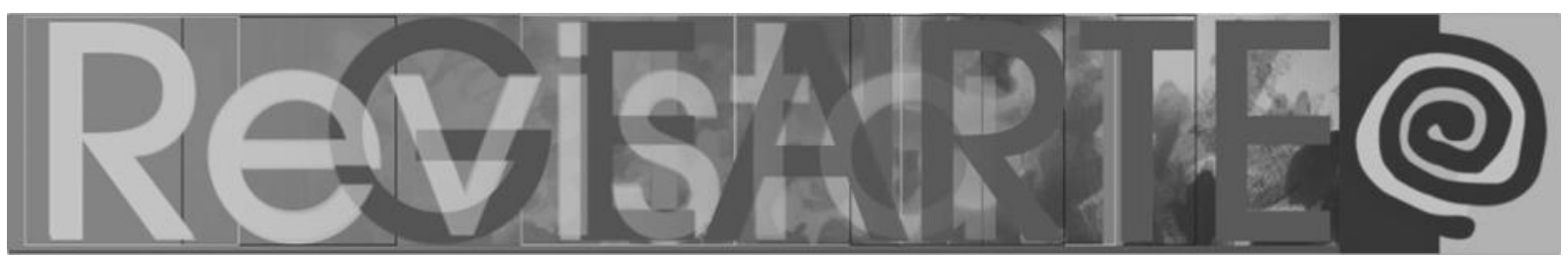

além do rabisco; O que podemos aprender com a cidade sobre arte, cultura e educação? O que podemos ensinar sobre arte, cultura e educação a partir da cidade; Ideias para o futuro; Pensar e fazer arte na escola: artes visuais, música e movimento (dança/teatro). Vejamo-las a seguir.

\section{Proposição: A poética pessoal para transver o mundo}

Para uma aprendizagem inventiva, faz-se necessário, ao professor, um “[...] baú com instrumentos de trabalho: um abridor de amanhecer, um prego que farfalha, um encolhedor de rios e um esticador de horizontes", como diz Manoel de Barros no Livro das Ignorãças (1993, p.27). Nessa obra, o poeta perambula por "[...] uma didática da invenção, os deslimites da palavra e o mundo pequeno" (BARROS, 1993, p. 29) e, nos conta que desde "[...] menino gostava mais do vazio do que do cheio" (BARROS, 1993, p.59).

Assistimos ao documentário "Só dez por cento é mentira. A desbiografia oficial de Manoel de Barros" (SÓ, 2009c), dirigido pelo mineiro Pedro Cezar ${ }^{5}$. Os estudantes compartilharam os momentos que mais os afetaram durante a exibição e quais despropósitos trazem para si, para as crianças e para a educação. Também, foram convidados a apresentar, posteriormente, objetos ou produções artísticas, como abridores de horizontes para transver o mundo.

Tudo que não invento é falso! Tudo que não invento é falso!

Tudo que não invento é falso! Tudo que não invento é falso!

Tudo que não invento é falso! Tudo que não invento é falso!

(SÓ, 2009c)

\section{Proposição: $O$ desenho para além do rabisco}

Segundo Manoel de Barros, as manchas nas paredes podem ser muito mais do que manchas. O poeta diz no documentário (SÓ, 2009c): "Imagens são palavras que nos faltam"... As crianças não dominam as palavras, "[...] erram na gramática, acertam na poesia" e só desenham o que sua imaginação produz. $O$ tema do desenvolvimento gráfico infantil pode ser empregado na escola em diferentes situações, seja na ampliação de repertório, 


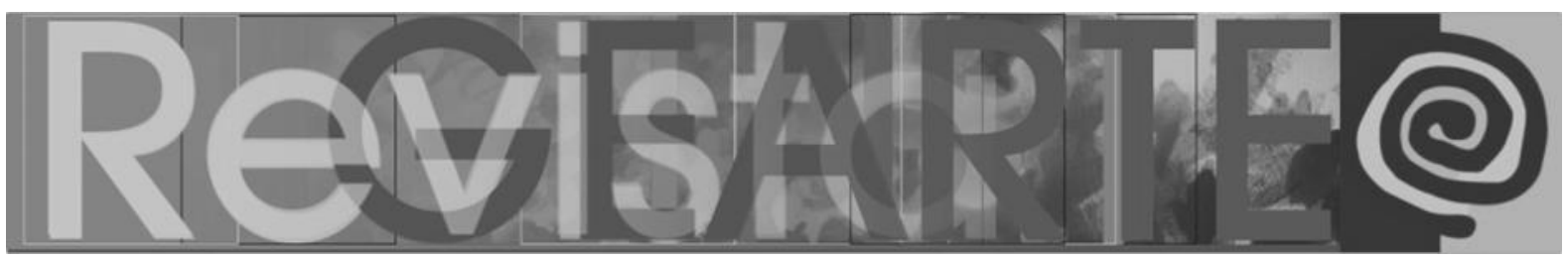

nas escolhas estéticas mais adequadas à faixa etária, inclusive para esclarecer tais escolhas estéticas junto aos demais professores, direção e/ou pais.

Proponho então a leitura do livro $O$ Espaço do Desenho: $A$ Educação do Educador, da professora Ana Angélica Albano e produção de um texto reflexivo com depoimento à autora sobre as ideias para a sua futura docência. Observação de desenhos infantis e de artistas desenhistas e a produção dos próprios desenhos.

\section{Proposição: 0 que podemos aprender com a cidade sobre arte, cultura e educação? O que podemos ensinar sobre arte, cultura e educação a partir da cidade?}

A expedição ao Centro Histórico da cidade de Tiradentes (Minas Gerais), viabilizou, ao futuro professor, aprender sobre arte e cultura no espaço urbano, além de ampliar os horizontes dos territórios da arte e da cultura para além dos muros da escola e dos estereótipos recorrentes nas aulas de arte. Após a visita e de posse dessa experiência comum, trabalhamos individual e coletivamente com as produções artísticas realizadas (fotografias, desenhos, colagens) e com as concepções contemporâneas de ensino e de aprendizagem da arte na escola, bem como com as questões relativas ao professor mediador, à visualidade, interculturalidade, identidade e pertencimento inerentes à cidade e ao espaço público.

A cidade de Tiradentes dista $152 \mathrm{~km}$ de Juiz de Fora. Esse deslocamento, com ônibus institucional, foi viabilizado através do Programa Territórios Educativos ${ }^{6}$, promovido semestralmente pela Pró-reitoria de Graduação da UFJF, que afirma que "[...] a possibilidade formativa trazida pelas viagens técnicas, trabalhos de campos e outras imersões a diferentes territórios educativos configura-se em importante estratégia de formação teórica, prática e cidadã" (UNIVERSIDADE FEDERAL DE JUIZ DE FORA, 2019). 


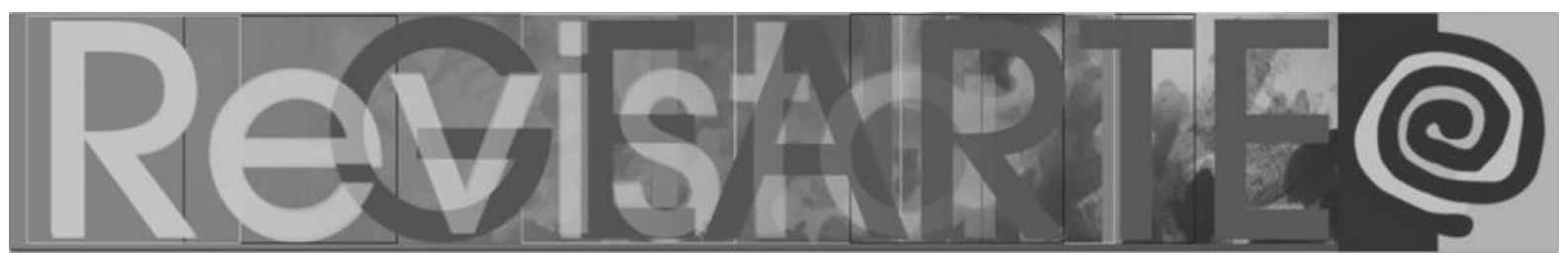

\section{Proposição: Ideias para o futuro}

De modo geral, alunos e alunas da pedagogia chegam bastante indecisos e inseguros em relação à disciplina de arte. Daí, investimos na ampliação de repertório, incentivando-os a manterem-se abertos às diferentes metodologias artísticas e deixar brotar fissuras nas coisas acostumadas que se apresenta como escola/universidade. Entre as fissuras, pretende-se cartografar o currículo, como nos ensina Tomaz Tadeu Silva (2004):

\footnotetext{
O currículo tem significados que vão muito além daqueles aos quais as teorias tradicionais nos confinaram. O currículo é lugar, espaço, território. O currículo é relação de poder. O currículo é trajetória, viagem, percurso. O currículo é autobiografia, nossa vida, curriculum vitae: no currículo se forja nossa identidade. O currículo é texto, discurso, documento. O currículo é documento de identidade. (SILVA, 2004, p. 47)
}

Também, pretende-se experimentar e ir junto, isto é, deixar-se contaminar pela experiência de conhecer e conhecer-se em lugares de risco, mutações, incertezas e impermanências. Sempre na busca por desacostumar as palavras e as coisas ao sabor da experiência - dos alunos e da nossa própria. Para tal, exercitamos algumas das proposições defendidas por Mirian Celeste Martins e Gisa Picosque (2012), entre outras, descritas brevemente a seguir:

- curadoria educativa: atitude, um modo de "[...] operar consciente na escolha criteriosa do explorar a potência da arte como veículo de ação cultural, constituindo-se como uma proposta de dinamização de experiências estéticas junto ao objeto artístico exposto perante um público diversificado" (MARTINS; PICOSQUE, 2012). A ideia de curadoria educativa está articulada tanto à construção do olhar, quanto à possibilidade de ativar culturalmente as obras/produções escolhidas intencionalmente para apresentar aos alunos/observadores.

- nutrição estética: ações planejadas para provocar aproximações/encontros com a arte, mesmo sem gerar um trabalho mais específico sobre ela. Nesse sentido, entende-se a nutrição estética, como uma oportunidade de 


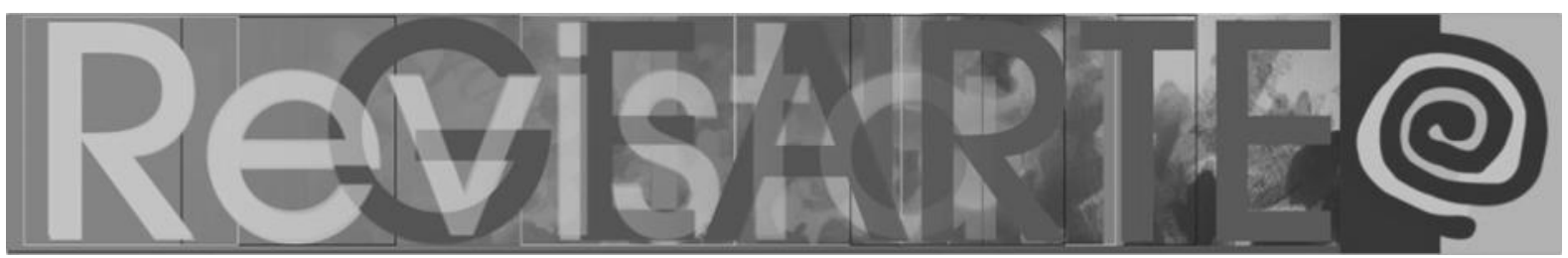

enriquecer o grupo de estudantes com poesia, fragmentos de filmes e músicas, imagens, obras de arte, produções de crianças/jovens para alimentar olhares, percepções e pensamentos.

- mediação cultural: Nas áreas de educação, arte e cultura, o estar no meio implica complexa posição de estar entre, que possibilita uma rede de múltiplas provocações e possibilidades de relações entre sujeitos, objetos, espaços e contextos envolvidos. Um território potente de tensões que abrange estranhamentos, surpresas, choque, indignação, afinidades, gostos, resistências, aberturas, diálogos, trocas, percepções ampliadas, empatia, alteridade. Ao considerarmos o ser humano como um ser histórico e social inserido em sua cultura, a mediação é compreendida como interação e diálogo que valoriza e dá voz ao outro, ampliando horizontes que levam em conta a singularidade dos sujeitos em processos educativos na escola ou fora dela.

- professor propositor: Para Lygia Clark e Hélio Oiticica, o artista é o propositor. "Nós somos os propositores: nós somos o molde. Nós somos os propositores: nossa proposição é o diálogo. Sós, não existimos", diz Clark (1983). Assim, também um professor pode ser propositor quando lança seus aprendizes na criação, na produção de sentidos, no enfrentamento do não saber. Movemos o outro e a nós mesmos para viver experiências estéticas, não mais da maneira espontaneísta da escola, que só valorizava o fazer, mas na consciência de si, na percepção dos próprios processos de criar, pensar, produzir significados, de se colocar vivo na experiência, de compartilhá-la com outros na conversa que se torna

- territórios da arte \& cultura: novos encaminhamentos para a arte na escola a partir da Mediação Cultural, Linguagens Artísticas, Materialidade, Processos de Criação, Patrimônio Cultural, Forma e Conteúdo, Saberes Estéticos e Culturais, entre outros a arquitetar. 


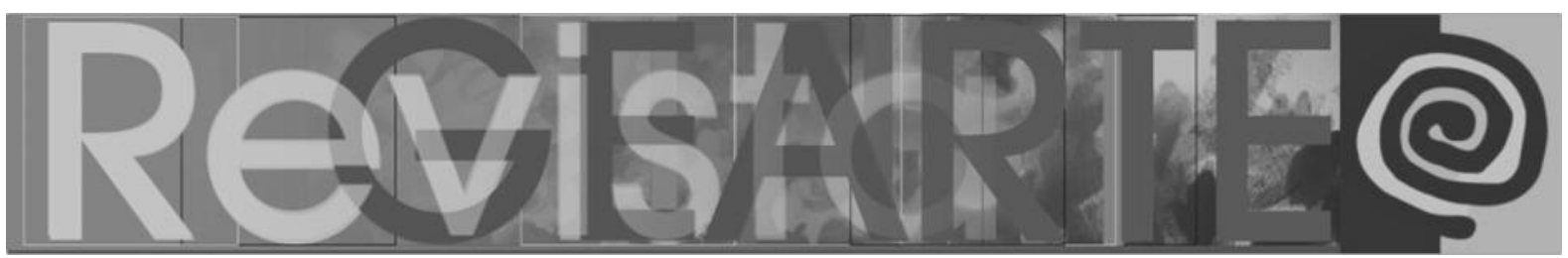

- painel coletivo: observação coletiva do conjunto das produções a partir da visão geral e individual, estimulando a conversação sobre semelhanças e diferenças, rememorando a proposição inicial (e a possibilidade do refazer); qualidades visuais que chamam a atenção (análise formal) e possíveis desacertos (seja nos processos de criação; compreensão ou não da proposta; necessidade de retomar as orientações por parte do professor; visão geral da turma x expectativa do(a) professor(a); avaliação do aluno/avaliação do professor).

\section{Proposição: Pensar e fazer arte na escola: Artes visuais, música e movimento (dança/teatro)}

Construção e/ou ampliação do repertório teórico e prático sobre as linguagens artísticas na Educação Infantil e Séries Iniciais do Ensino Fundamental, para realizar escolhas estéticas que sejam adequadas à faixa etária e ao contexto dos alunos e da escola. Professores especialistas e atuantes em cada área, são convidados a apresentar sua experiência cotidiana e propor uma oficina aos estudantes. Após as leituras indicadas e as vivências, os alunos sintetizam as supressas e os estranhamentos, respondendo ao questionamento: o que você sabe agora que não sabia antes sobre as linguagens artísticas na Educação Infantil e Séries Iniciais da Educação Fundamental? 


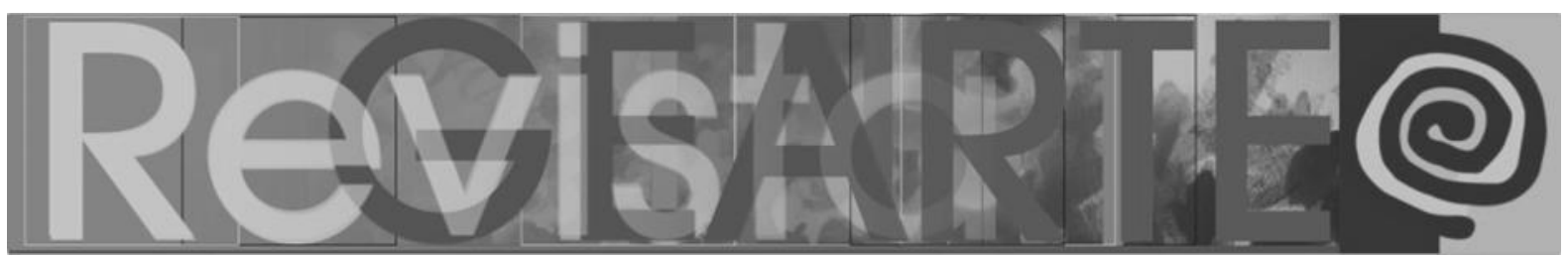

Figura 2 - Aprendizagens II
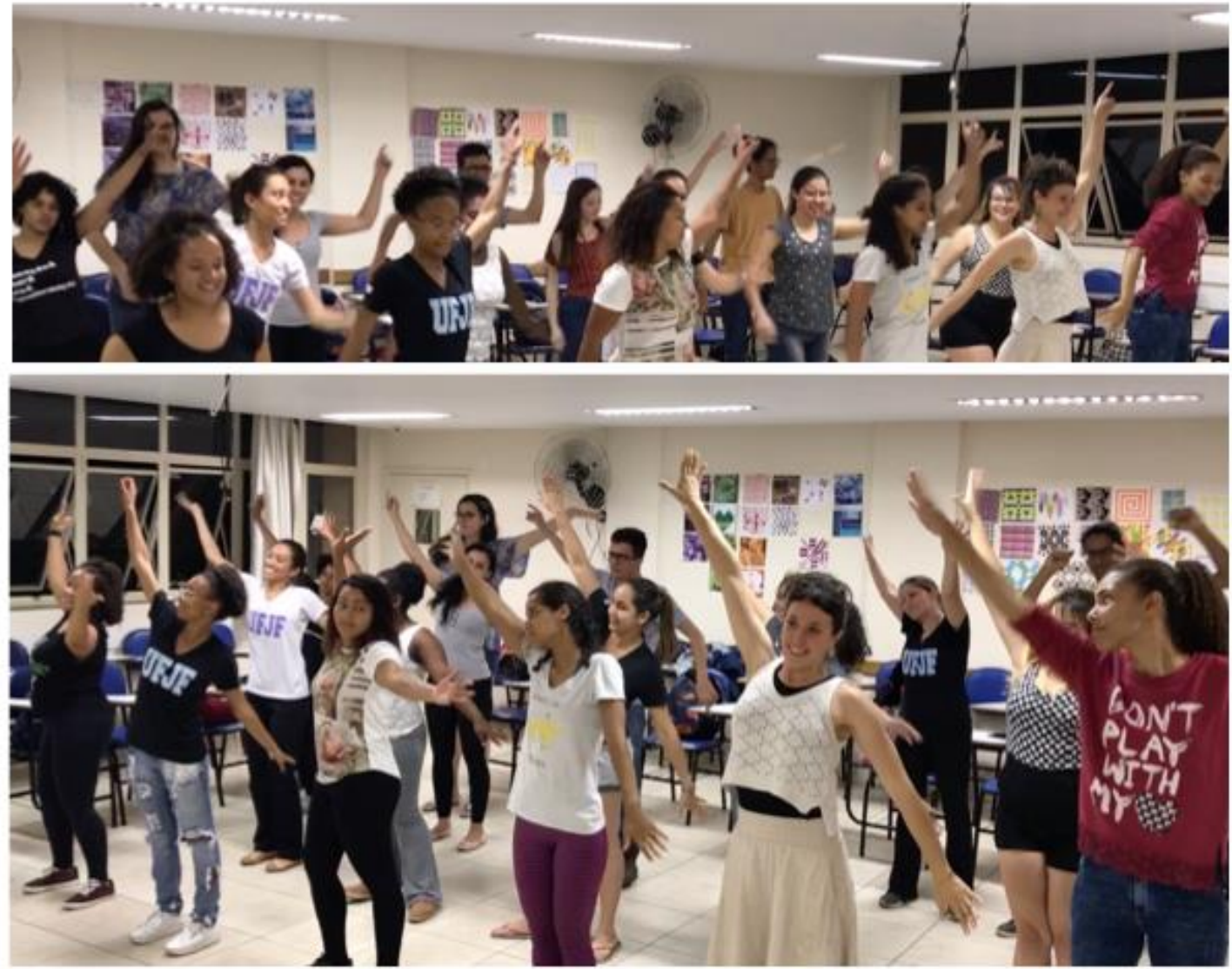

Fonte: Acervo da autora (2019)

\section{Última aula}

Para vivenciar a aprendizagem inventiva, todos os professores necessitam de um "[...] baú com instrumentos de trabalho: um abridor de amanhecer, um prego que farfalha, um encolhedor de rios e um esticador de horizontes", como diz Manoel de Barros no Livro das Ignorãças (1993, p. 25). Nesta obra o poeta perambula por uma didática da invenção, os deslimites da palavra e o mundo pequeno. (BARROS, 1993, p.53).

No último encontro, tentando compreender os vazios e os cheios da disciplina, propus a realização de uma autoavaliação com perguntas predefinidas, com a intenção de verificar como e se os alunos perceberam a aula como acontecimento e, também, o currículo abordado como potência de invenção de 


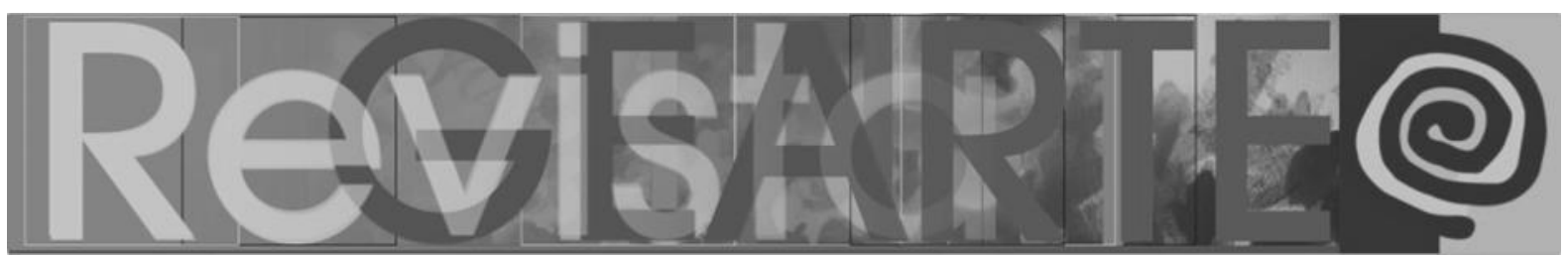

problemas. Ao elaborar as respostas, o estudante teria oportunidade de tomar consciência de sua própria caminhada?

Dividida em duas partes, a autoavaliação questiona a ampliação de conhecimento e o aproveitamento na disciplina. As respostas para as cinco questões da primeira parte foram lidas em classe e comentadas por todos. Neste momento, a turma tem 28 alunos matriculados, dos quais 24 responderam a autoavaliação, cujos depoimentos conheceremos a seguir.

Para a primeira questão: Você considerou pertinente refletir sobre a educação, o professor e a arte na escola nesta disciplina obrigatória? Alice, Talita, Eduarda e Célia, nessa ordem, respondem:

\begin{abstract}
A disciplina me fez ampliar a visão do contexto escolar atual; de como ainda é problemático, mecanizado e por mais que existam tentativas de modificar o ensino estereotipado, parece que permanecemos girando em círculos, caindo na mesmice. A disciplina trouxe discussões e métodos de como é possível - e necessário - ensinar arte além da caixinha.

$\mathrm{Na}$ minha escolarização a arte foi pouco presente e pouco explorada. $\mathrm{Na}$ disciplina, pude ver como a arte é um amplo universo, podendo ser trabalhada de várias formas e que tipo de atitudes já posta devemos repensar.
\end{abstract}

A partir dos temas discutidos nas aulas, pude aprender sobre a relação das crianças com a arte e rever alguns pensamentos que tinha antes.

Acho que essa reflexão serviu para ampliar meus horizontes e dos colegas da disciplina, enquanto futuros educadores. Algumas disciplinas nos fazem refletir por recortes de diferentes temas e quando nós alunos chegamos nesta disciplina esperávamos algo mais relacionado com o fazer. Contudo, pude perceber que a disciplina vai além, e é importante ir além dessa visão. (informação verbal) ${ }^{7}$.

As respostas evidenciam a importância da manutenção e, se possível, do aprofundamento das discussões sobre arte como linguagem e conhecimento para combater o senso comum vigente, defasagem decorrente da formação cultural precária ou inexistente entre os estudantes do curso de pedagogia. No entanto, todos os alunos foram unanimes em considerar a relevância das reflexões realizadas para si mesmo e para a efetiva presença da arte na escola. 


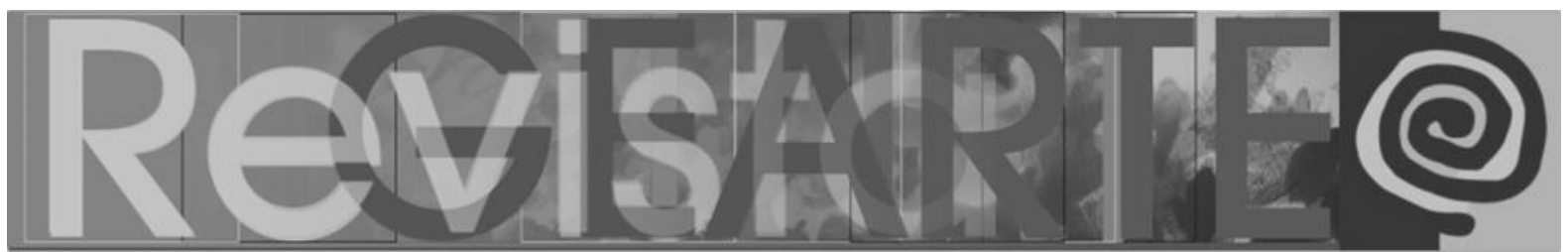

A segunda questão versa sobre a consciência da apropriação de novos conhecimentos. As respostas para: Você compara o que aprendeu na disciplina com o que sabia a respeito e percebe avanços? Quais? corroboram que houve produção de novos significados para a arte como um saber específico e potência expressiva, junto às crianças e adultos, como afirmam Guilherme, Amanda, Giulia, Hozana, Reisla e Maiara:

Antes dessa matéria, tinha parado poucas vezes para pensar sobre como a arte atua na educação infantil. Posso dizer que cheguei sem nenhuma noção sobre o assunto e saí cheio de ideias e vontade de aplicar os conhecimentos que adquiri. Creio que o avanço foi na minha sensibilidade para entender como as crianças se expressam e em como o professor influenciam diretamente no desenvolvimento da criança, mostrando que ser professor exige, além de várias outras habilidades, muito cuidado e atenção.

Sempre tive consciência que o ensino de artes é importante nas escolas. As atividades propostas na disciplina possibilitaram minha autocrítica, pois consegui perceber que arte não existe apenas nas aulas de "educação artística". Afinal, como sou professora atuante na disciplina de geografia encontrei diversas formas de atrelar a arte com a ciência geográfica, por exemplo, ao trabalhar o conceito de territórios através da fotografia.

A disciplina me fez desconstruir conceitos que socialmente estavam impregnados em minha cabeça. Por exemplo, achar que o desenho de algo tem que ser muito fiel a realidade, e se não for fiel, é um problema. Hoje percebo que não há certo e errado. Não seguir o que está padronizado não é um problema, mas sim, a exibição da criatividade pessoal. Esses momentos são muito ricos e devem ser valorizados, sem serem apontados como erro. O melhor jeito de se expressar é o nosso próprio.

Compreendi a importância do ensino da arte nas escolas e como ela pode fazer a diferença no processo de aprendizagem dos alunos.

A disciplina me proporcionou mudar o olhar com relação a muitas coisas ligadas à Arte. A leitura do "O espaço do desenho: a educação do educador", abriu meus olhos para aspectos ligados aos desenhos das crianças que antes passavam despercebidos e, associados à vivência que eu tive no meu estágio, mostrou o quanto o desenho das crianças "fala" e reflete muito delas. Um dos maiores avanços que percebo é conseguir olhar para as produções das crianças com outros olhos, parar de buscar a "perfeição" nas produções e reconhecer o quanto delas está presente ali.

Eu sabia muito pouco em relação à arte na escola, justamente pela falta de experimentação na minha época de estudante. Sempre soube que era importante, e isso foi confirmado. (informação verbal) ${ }^{8}$. 


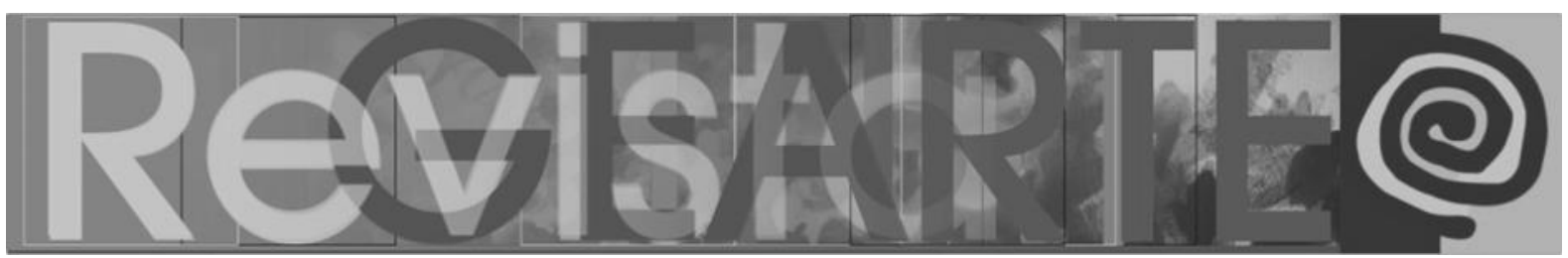

Nas respostas acima observamos que há maior compreensão sobre a importância da arte na escola e o quanto o tema é invisível não apenas entre os estudantes, mas para os demais professores formadores tanto quanto para os professores regentes e para as equipes diretivas das escolas. Observamos, nos depoimentos acima, o desejo em garantir maior visibilidade para a arte na escola. Que assim seja!

Nos depoimentos de Ariel, Amanda, Letícia M. e Talita entendemos que a percepção de si permanece incompleta se não pudermos descobrir como cada um de nós é o outro do outro, em especial, nos vínculos construídos entre professores e alunos - a partir do questionamento: Você gostou do que aprendeu?

Sim, acho que o principal de tudo é que agora tenho mais dúvidas sobre as certezas que eu acreditava ter, o que me provoca a estar sempre aberta a aprender mais sobre arte e educação.

Gostei, especialmente, do percurso da disciplina, que ajudou a refletir sobre a prática e atribuir novos significados para os espaços coletivos na escola. Todo o ambiente passou a ser possibilidade de ensino e aprendizagem. O adulto precisa respeitar as crianças em suas individualidades e expressões artísticas, parar com aquele famoso retoque final do trabalho e valorizar as produções infantis.

Muito. Essa disciplina possibilitou muitas discussões e reflexões sobre a arte e sua importância na escola hoje. Ampliou minha forma de pensar e ensinar arte para as crianças e valorizou a importância do olhar atento e sensível em diálogo com aquela delicada garatuja ou outra produção artística.

Gostei do que aprendi e da forma como adquiri esse conhecimento, pois o suporte teórico eram leituras de fácil entendimento. As aulas foram muito participativas, convidando todos a participar dos temas abordados, trazendo mais envolvimento e nos estimulando a colocar a mão na massa, instigando a imaginação e quebrando o paradigma do eu não sei fazer ou não consigo fazer. (informação verbal) ${ }^{9}$

As respostas acima apontam para as dúvidas e incertezas futuras, o desejo de aprender mais, a compreensão teórica a partir da prática, do respeito e de um olhar sensível em sala de aula. Para nisso acreditar, é fundamental vivenciar tais circunstâncias ainda na formação inicial. 


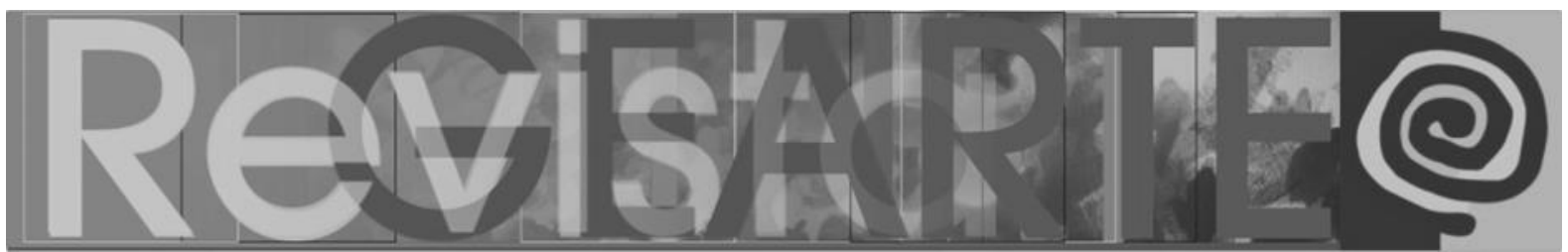

A quarta questão investiga se os novos conhecimentos foram incorporados ao cotidiano dos estudantes e se já fazem parte da postura profissional desejável contemporaneamente. Selecionamos os depoimentos de Ana Paula, Eduarda, Gabriela, Hugo, Luana, Letícia M., Ludmila e Vanessa, como exemplos de respostas para a questão: Você conseguiu estabelecer links entre a disciplina e o seu dia a dia, aplicando o que aprendeu?

Sim, acompanho uma turma de educação infantil e muitos dos elementos citados observei na prática. Também, testei alguns exercícios de movimento e música no qual professores convidados mostraram nas oficinas.

Através dessa disciplina, pude relacionar algumas coisas que aprendemos com minha experiência no PIBID, em uma creche, e também no estágio, numa turma de $3^{\circ}$ ano, porém foram duas situações muito distintas. Na creche, as crianças já têm bastante contato com a arte e lá desenvolvi um projeto com foco nas brincadeiras com tinta de terra. Foi tudo maravilhoso. Já no estágio, percebi que as crianças gostavam muito de desenhar, mas quase nunca eram incentivadas a fazer isso e, quando faziam, deviam seguir um padrão. Pensando nisso, fiz minha intervenção com tinta de terra, já que havia sido uma experiência muito boa para mim e também foi uma oportunidade para aquelas crianças terem contato com outro tipo de material e se expressarem mais livremente.

Sim, tenho uma filha de 8 anos que é muito indisciplinada na hora dos deveres. Por isso, tenho trabalhado as questões de movimento entre as tarefas e ela tem conseguido externar as emoções e momentos mais proveitoso de estudos. Em outros momentos, estamos deixando de lado as brincadeiras monótonas dos brinquedos industrializados e construindo nosso próprio repertório de brinquedos, com caixas de leite e o auxílio de tintas e outros materiais. Além de Maria estar desenvolvendo habilidades estamos nos aproximando ainda mais.

Posso resumir na seguinte afirmação: há um artista dentro de mim, esse artista sou eu. Voltei a desenhar, fazer poesias, ouvir mais músicas, tanto novas como redescobrir músicas, agora novas de outra forma. Além disso, ando nas ruas observando estampas nas roupas das pessoas e pensando como foram feitas. Vejo paletas de cores em outdoors. Vejo histórias pessoais nos desenhos de meus alunos, ouço músicas pensando se são boas para minhas crianças.

Comecei a observar mais como o professor e as crianças estabelecem uma relação com a arte na escola, além de compreender melhor as concepções sobre a construção do desenho pelas crianças, suas fases e seus processos de criação. A partir das discussões e leituras propostas pela disciplina, consigo ver na prática diversas situações analisadas durante nossos encontros.

Sim. Aprendi a observar os detalhes e lugares, que antes passavam despercebidos. 


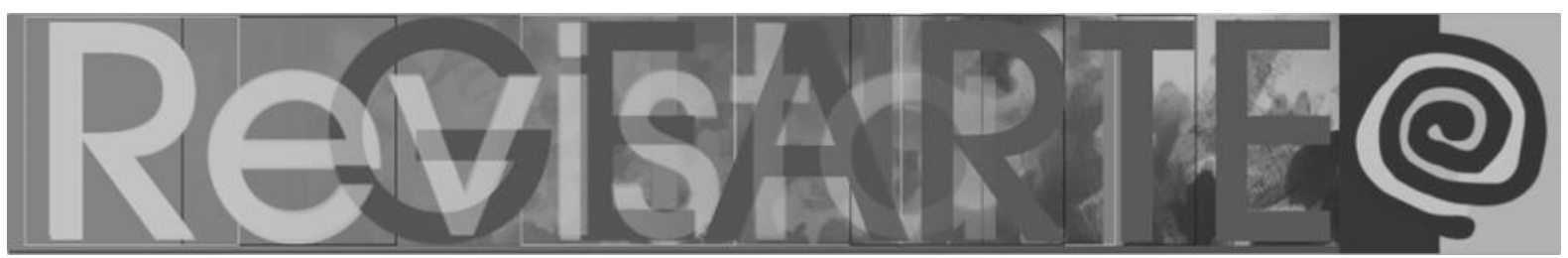

Agora, quando vejo meu sobrinho de dois anos desenhando, observo como os movimentos realmente são amplos, envolvendo o braço todo e não somente o movimento do punho, tal como a professora apontou. Além disso, observo também o formato, que ele já está fazendo bolinha e começando utilizar os desenhos como forma de representação: ele já faz paínho (passarinho), cavalo... Por meio da disciplina também passei a frequentar mais exposições artísticas, como a exposição das creches do município, a mostra Professor Também Faz Arte e a exposição, no MAMM, do projeto Arte em Trânsito, desenvolvido no Colégio de Aplicação João XXIII. Durante as visitas, me lembrei de muitos conhecimentos discutidos na sala de aula, como por exemplo, na exposição do MAMM, quando vi imagens dos trabalhos lambe lambe. Antes da disciplina ficaria confusa sobre o que era lambe lambe, mas na hora conseguir estabelecer link com a vivência em sala de aula.

Sim. Esse semestre eu tive uma experiência bem desafiadora de estágio, onde eu atuei por um tempo junto a uma turma de $4^{\circ}$ ano com alguns alunos não alfabetizados e com dificuldades de se comunicarem sem ser aos gritos. Eu tentei me aproximar deles de alguma forma e percebi que eles gostavam muito de desenhar. Eu me lembrei de nossas discussões em sala sobre o desenho enquanto forma de expressão e comunicação e comecei a observar melhor essas crianças, que eu imaginava não saber se comunicar umas com as outras. Elas não sabiam escrever, não percebiam a sala de aula como um lugar onde elas pudessem falar ou se movimentar, então elas desenhavam. Eu reparei que elas gostavam de desenhar e comecei a elogiar de forma sincera os desenhos, e, naquele dia, eu fui embora com três desenhos de crianças tidas como problemáticas. A partir do momento, que eu olhei para o desenho delas, com um olhar diferente daquele que repreende por estar desenhando em sala de aula (quando deveriam estar aprendendo), nossa relação mudou. Acho que elas precisavam se sentir reconhecidas e incluídas de alguma forma. (informação verbal) ${ }^{10}$

Os depoimentos relatam, por si mesmos, a surpresa e a alegria em perceber que o conhecimento apresentado na Faculdade de Educação tem consistência e relevância em sala de aula. Frequentemente, há muitas críticas em relação aos saberes produzidos na academia e ao seu distanciamento do chão da escola e das práticas docentes necessárias às demandas atuais da Educação Infantil e dos anos iniciais da Educação Infantil. As falas tangenciam as iniciativas docentes e a descoberta de suas poéticas pessoais.

Para a questão Você já conseguiu transmitir um conhecimento adquirido na disciplina para outra pessoa?, Alice, Ana Beatriz, Virginia, Hozana e Roberta nos contam que: 


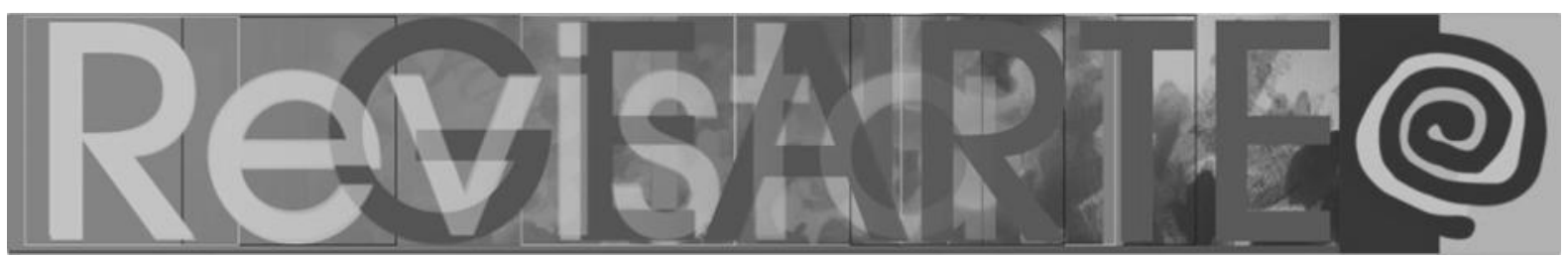

Comentei sobre a importância do desenho para a professora que me orienta na escola (e ela automaticamente deu um jeito de encaixar o desenho na rotina dos alunos - mesmo que a supervisora tenha basicamente dito que as crianças não viam sentido em rabiscar) e a evolução em apenas algumas semanas foi notória; muitas crianças saíram da garatuja.

Praticamente sim, com meu filho em casa, quase tudo o que aprendo na faculdade quando chego em casa tento aplicar ou fazer o melhor.

Tive a oportunidade fazer uma intervenção com o tema musicalização na escola onde realizo meu estagio obrigatório. As crianças se divertiram muito e eu fiquei muito feliz de poder compartilhar com eles uma aula que aprendi na UFJF.

Felizmente já. Estou no projeto do PIBID, faço parte do eixo de ciência e tecnologia, estou ajudando a professora na produção da feira de ciências que ocorrerá no dia 23/11. O tema da minha turma são os animais terrestres e tudo que vai ser exposto está relacionado de alguma forma com as artes visuais: são pinturas (alguns alunos estão fazendo animais silvestres e insetos usando as mãos e os pés pintados como base e depois decorando pra ficar mais semelhante), esculturas das casas dos animais como abelha, joão-de-barro, formigueiro e aranha (eles estão utilizando diferentes materiais para essas construções como argila, papel higiênico com cola e água, rolos de papel higiênico, fita crepe) e colagem (a partir do livro infantil Direito dos Animais, utilizam papel picado, fios e linhas, jornais, revistas, palitos, etc.). As ideias para feira foram decididas por mim, juntamente com a professora, ela apresentou a proposta da pintura e da colagem e eu das esculturas. E nessa semana a produção está a todo vapor para preparar todos os materiais.

Estou no processo de desconstrução com relação à perfeição das produções artísticas das crianças e a professora do meu estágio iniciou esse processo junto a uma colocação minha relacionada a isso. Ela estava extremamente preocupada, pensando que não ia dar conta e não queria deixar que os alunos finalizassem os trabalhos, dizendo: "Ah não, eles vão estragar", "mas isso vai ficar borrado e desproporcional", "olha lá como ele é desajeitado, se eu der na mão dele já sei que vai fazer cagada". Então, disse a ela "o que adianta o trabalho ficar perfeito se não foram feitos pelos alunos? Os pais vêm aqui não para ver perfeição e sim para ver o que o filho fez, sem contar que o trabalho tem que ter a cara deles!". Ela pensou e decidiu deixar que eles fizessem... No final, o aluno que ela disse que faria cagada fez um dos animais mais bonitos e ela se surpreendeu muito! Acredito que isso tenha sido um reflexo de tudo que vi na disciplina, e espero ter conseguido mudar pelo menos um pouquinho a percepção dessa professora. (informação verbal) ${ }^{11}$

Bem, se por um lado, os depoimentos revelam que as estudantes estão empolgadas em expor os conhecimentos recém-descobertos sobre arte e seu ensino, por outro, escancaram situações e práticas docentes preocupantes em relação à falta de preparo e sensibilidade dos regentes de sala. Essa é uma longa 


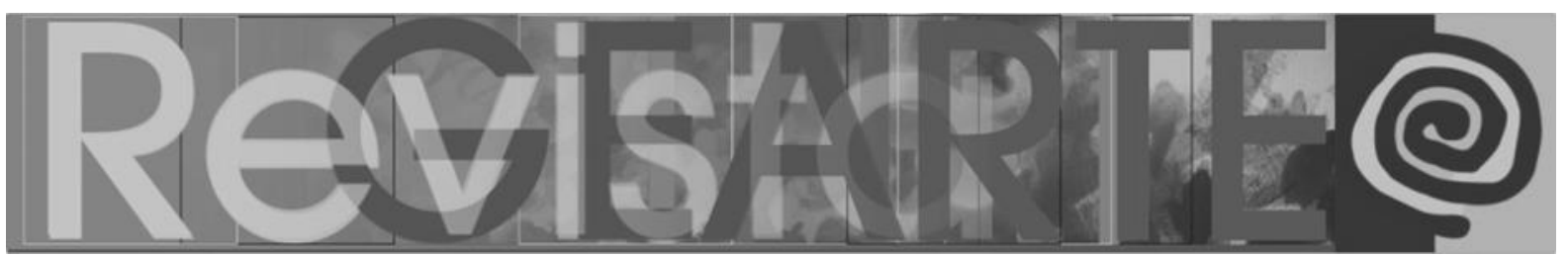

batalha contra o senso comum das aulas, arraigado nas entranhas das escolas, que subestimam os alunos e a si próprias, estacionam no tempo e descuidam de sua formação continuada. Que Alice, Ana Beatriz, Virginia, Hozana e Roberta e todos os demais depoentes, possam fazer a diferença em sua caminhada profissional.

Caminhando para a finalização deste relato sobre o início e o término de um percurso possível para a disciplina Fundamentos Teóricos Metodológicos em Arte I, constato o quanto a atitude de ir junto e acreditar no que já está lá pode responder aos inúmeros desafios e às responsabilidades que compartilho com os estudantes, futuros professores.

Encerramos a última aula entre abraços e sorrisos. Quando todos se vão, arrumo meu material, apago as luzes e fecho a porta. Desço lentamente as escadas, sentindo saudades de estar entre todos e todas outra vez.

Figura 3 - Aprendizagens III

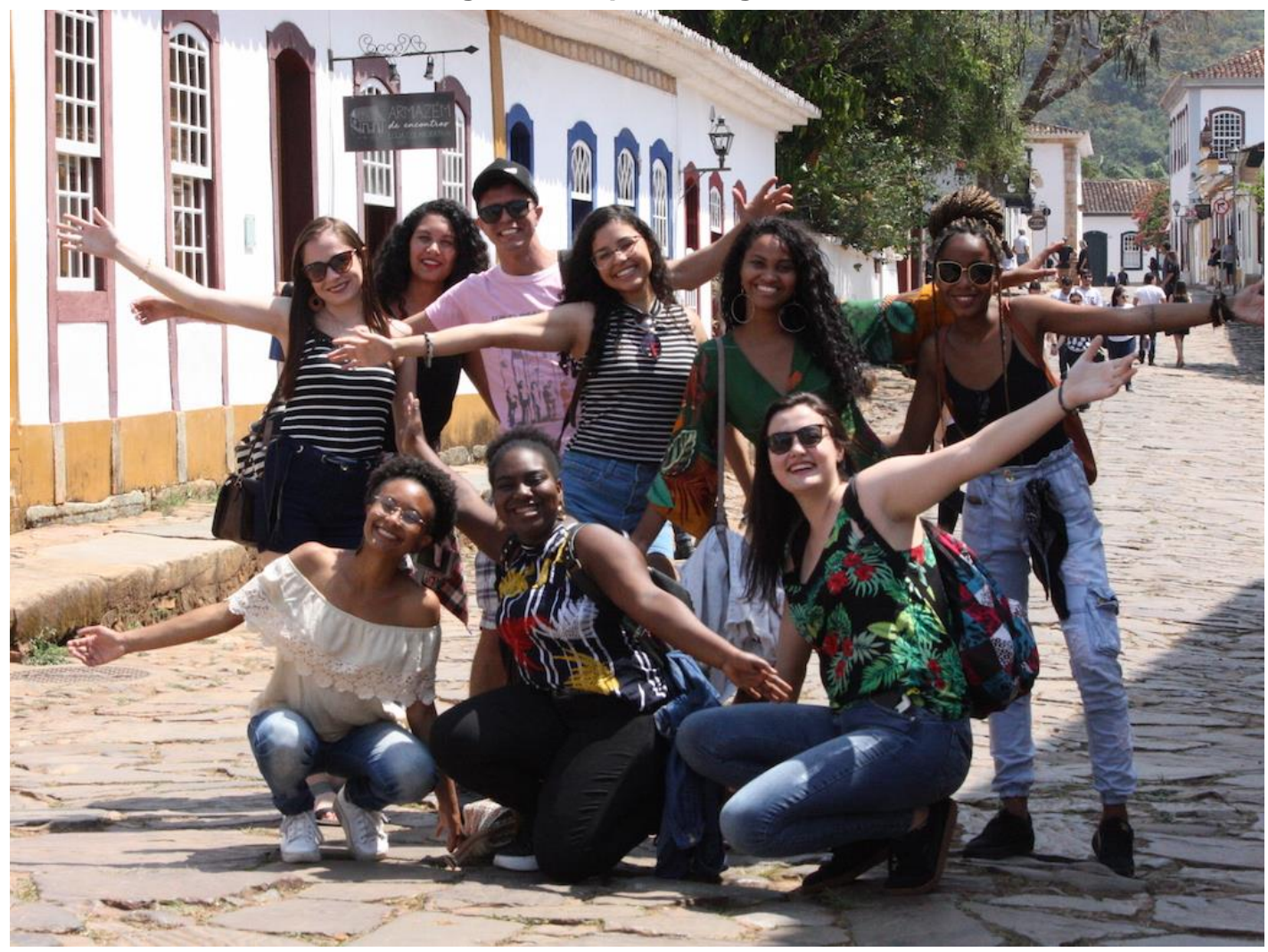

Fonte: Acervo da autora (2019).

EGAS, Olga. Desaprendizagens permanentes: experiências com a arte na Pedagogia.

Revista GEARTE, Porto Alegre, v. 8, n. 2, p. 253-278, maio/ago. 2021.

Disponível em: http://seer.ufrgs.br/gearte 


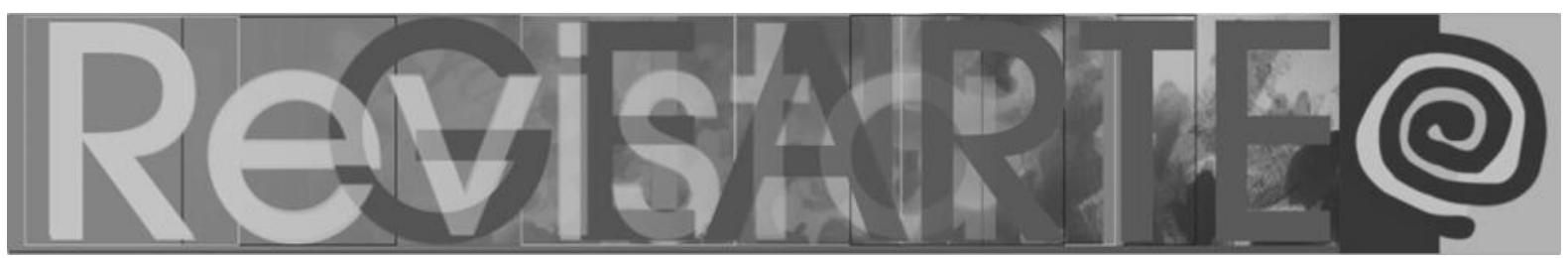

\section{Notas}

1 As disciplinas eletivas oferecidas pela área a cada semestre, exploram diferentes perspectivas da arte e da cultura e são oferecidas aos licenciandos de Pedagogia, Artes Visuais e História, visando a construção colaborativa e interdisciplinar de conhecimentos. São elas: Arte e as Infâncias, Teatro na Educação e Arte Cultura Afro-brasileira, descrita por Francione Oliveira Carvalho no artigo $A$ arte e a cultura afro-brasileira como descentramento sensorial na Pedagogia.

2 O termo desperiodicizado se refere aos alunos matriculados em diferentes períodos acadêmicos.

3 FUNALFA - Fundação Cultural Alfredo Ferreira Lage, da Prefeitura de Juiz de Fora, que entre outras ações, oferece gratuitamente oficinas de teatro, desenho, flauta, percussão, artesanato, capoeira e dança urbana para o atendimento de crianças, adolescentes e jovens em idade escolar, matriculados na rede de ensino e com risco de vulnerabilidade social. As oficinas são ministradas por articuladores culturais em dois encontros semanais.

4 Versão dublada, disponível em: https://www.youtube.com/watch?v=DA0eLEwNmAs. Acesso em: 30 abr. 2020. O texto traduzido completo está disponível em: http://blog.brasilacademico.com/2011/09/mudandoparadigmas-na-educacao.html. Acesso em: 30 abr. 2020.

5 O documentário completo está disponível em: https://www.youtube.com/watch?v=OaXiOwnP2bQ. Acesso em: 30 abr. 2020.

6 O Programa Territórios Educativos também foi abordado pelo professor Francione Oliveira Carvalho no texto $A$ arte e a cultura afro-brasileira como descentramento sensorial na Pedagogia.

7 Resposta das alunas Alice, Talita, Eduarda e Célia para a pergunta: Você considerou pertinente refletir sobre a educação, o professor e a arte na escola nesta disciplina obrigatória? do questionário de autoavaliação.

8 Resposta de Guilherme, Amanda, Giulia, Hozana, Reisla e Maiara para a pergunta: Você compara o que aprendeu na disciplina com o que sabia a respeito e percebe avanços? Quais? do questionário de autoavaliação.

9 Respostas de Ariel, Amanda, Letícia M. e Talita, para a questão: Você gostou do que aprendeu? do questionário de autoavaliação.

10 Respostas de Ana Paula, Eduarda, Gabriela, Hugo, Luana, Letícia M., Ludmila e Vanessa para a questão: Você conseguiu estabelecer links entre a disciplina e o seu dia a dia, aplicando o que aprendeu?

11 Respostas de Alice, Ana Beatriz, Virginia, Hozana e Roberta para a questão: Você conseguiu transmitir um conhecimento adquirido na disciplina para outra pessoa? do questionário de autoavaliação.

\section{Referências}

ALBANO, Ana Angélica. O Espaço do desenho: a educação do educador. São Paulo: Loyola 2010.

BARROS, Manoel de. O livro das ignorãças. Rio de Janeiro: Record, 1993.

BARROS, Manoel de. Livro sobre nada. Rio de Janeiro: Record, 2000.

KASTRUP, Virginia. A invenção de si e do mundo: uma introdução do tempo e do coletivo no estudo da cognição. Campinas: Papirus, 1999.

KASTRUP, Virgínia. Políticas cognitivas na formação do professor e o problema do devir-Mestre. Educação \& Sociedade, Campinas, v. 26, n. 93, p. 1273-1288, set./dez. 2005. Disponível em: <https://www.scielo.br/pdf/es/v26n93/27279.pdf>. Acesso em: 30 abr. 2020. 


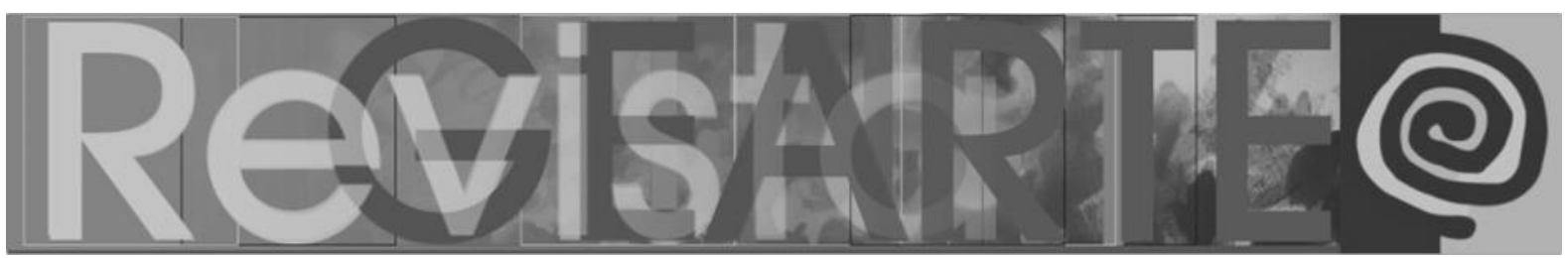

MARTINS, Mirian Celeste; PICOSQUE, Gisa. Mediação Cultural para professores andarilhos na Cultura. São Paulo: Intermeios, 2012

MUDANDO Paradigmas Educacionais. Produzido por Abi Stephenson. Dublagem por Blog Brasil Acadêmico. Londres: RSA Animate, 2003. (11min40.) Disponível em: <https://www.youtube. com/watch?v=DA0eLEwNmAs> Acesso em jul 2021.

SILVA, Tomaz Tadeu da. A filosofia de Deleuze e o currículo. Goiânia: FAV, 2004. (Coleção Debates Contemporâneos).

O FIM do recreio. Produção de Vinícius Mazzon e Nélio Spréa. [S.I.]: Parabolé Educação e Cultura, 2012. Disponível em: https://www.youtube.com/watch?v=t0s1mGQxhAl. Acesso em: 30 abr. 2020.

SÓ dez por cento é mentira. Produção de Pedro Cezar. [S. I.]: Artezanato Eletrônico, 2009c. Disponível em: <https://www.youtube.com/watch?v=OaXiOwnP2bQ>. Acesso em: 30 abr. 2020.

UNIVERSIDADE FEDERAL DE JUIZ DE FORA. Edital ํㅜ 3, de 02 de julho de 2019. [Edital interno de seleção de propostas de visitas técnicas, trabalhos de campo, viagens formativas no âmbito dos cursos de graduação no programa territórios educativos da graduação para o $2^{\circ}$ semestre de 2019]. Universidade Federal de Juiz de Fora: Pró-reitoria de Graduação, Juiz de fora, 2019.

\section{Olga Egas}

Professora nas Licenciaturas de Artes Visuais e Pedagogia da Universidade Federal de Juiz de Fora/MG. Graduada em Arte e Desenho. Mestre em Artes pela Universidade Estadual Paulista. Doutora em Educação, Arte e História da Cultura pela Universidade Presbiteriana Mackenzie. Coordenadora do MIRADA - Grupo de Estudos e pesquisa sobre Visualidades, Interculturalidade e Formação Docente e integrante dos Grupos de Pesquisa: Arte na Pedagogia - GPAP e Mediação Cultural: provocações e mediações estéticas - GPeMC.

ORCID: https://orcid.org/0000-0003-2295-959X

E-mail: olga.egas@uol.com.br

Recebido em 22 de fevereiro de 2021 Aceito em 30 de abril de 2021 